\title{
TRANSFER OF A PREDICTIVE MODEL FOR THE PRODUCTION OF PINE RESIN Pinus Spp A SMALL PRODUCERS IN EJIDO JORGE DE LA VEGA DOMÍNGUEZ, CINTALAPA, CHIAPAS
}

\author{
Cadena-Iñiguez, $\mathbf{P}^{1}$.; Reynoso-Santos, R. ${ }^{1}$; Hernández-Ramos, J. $^{2}$; Muñoz-Flores, HJ. ${ }^{3}$ and Cruz-Santos, $\mathbf{E}^{4}$ \\ ${ }^{1}$ Researchers of the Centro Experimental Center of Chiapas, of the National Institute of Forestry, Agriculture and \\ Livestock Research \\ ${ }^{3}$ Researcher of the Experimental Field Uruapan, Center for Regional Research Pacific Center, INIFAP. \\ ${ }^{4}$ Chiapas Regional Academic Center, Antonio Narro Autonomous Agrarian University (UAAAN)
}

http://doi.org/10.35410/IJAEB.2019.4414

\begin{abstract}
From 2016 and part of 2017, a series of activities were carried out to determine a mathematical model for the prediction of resin in pine trees in the community of Jorge de la Vega Domínguez, municipality of Cintalapa, Chiapas, southern state of The Mexican Republic, in order to predict and calculate the amount of resin that each tree can produce from the standardization of dasometric measurements, for which participatory research activities were carried out where the owners of the resource also participated in the training through the Field School sessions for the empowerment of tools that allow predicting resin production. The objective of this writing is to document the transfer process and the results that are currently available, which are very satisfactory for the owners and for the financiers of such activity.
\end{abstract}

Keywords: Resin, Pinus Spp, Transfer, Predictive Models.

\section{INTRODUCTION}

In the last decade, non-timber forest products (NTFPs) have been reconsidered as relevant elements of the integral management of forest ecosystems, because their collection helps to reduce the pressure on the arboreal communities and consequently, they are an important factor in the conservation of the same (FAO, 1999, Zamora et al., 2009). In Mexico, the National Forestry Commission (CONAFOR), as part of its Strategic Marketing Plan, includes as PFNM the following: pine resin, camedor palm (Chamaedorea elegans Mart.), Candelilla (Euphorbia antisyphilitica Zucc.), Oregano (Origanum vulgare L.), lechuguilla (Agave lechuguilla Torr.), Edible wild mushrooms, jojoba (Simmonsdia chinensis Link, Ckschneid.), Chewing gum (Manilkara zapota LPRoyen.) And guayule (Parthenium argentatum A.Gray.) (Romahn, 1992; CONAFOR, 2006). The use of pine resin worldwide amounts to just over one million tons where the main producers are: China, Brazil and Indonesia, these three countries reach a production of $1,200,000$ tons per year, representing $92 \%$ of world production (Cunningham, 2009b), which is mainly concentrated in three species: Pinus massoniana Lamb., P. elliotti Engelm and P. merkusii Jungh. \& de Vriese., (Cunningham, 2009a). Resin in Mexico in pine forests has been 
practiced since pre-Cortesian times; The Nahuatl, Toltec and Maya used resin as an adhesive for various ceremonial objects, and "turpentine" in torches used in night lighting (Mas and Prado, 1981). The use of pine resin for commercial purposes has been done since 1920, is the main nontimber forest product that is used in the country as it represents $43 \%$ and $47 \%$ of the value and volume of national non-timber forest production respectively. In Mexico the species with the highest resins production are: Pinus oocarpa Schiede ex Schltdl., $P$. devoniana Lindl., $P$. pringlei Shaw., P. montezumae Lamb., P. leiophylla Schltdl. \& Cham., P. teocote Schltdl. \& Cham., P. douglasiana Martínez., P. lawsonii Roezl ex Gordon., P. pseudostrobus Lindl and $P$. herrerae Martínez. The resin is produced in the central region of the country in the states of Michoacán, Jalisco, Estado de México and to the south in Oaxaca; the Michoacán resins production stands out, which makes up a little more than $90 \%$ of the national production (Hernández, J. 2011; CONAFOR, 2014).

In Chiapas the use of pine resin has been of little importance due to the lack of interest of forest owners, coupled with little or no knowledge of the benefits of this productive activity; In spite of there being indications in the municipalities of Cintalapa and Jiquipilas that, in previous years, this activity has been practiced. There are in La Frailesca, in the center of the state of Chiapas, pioneering communities in this activity: the ejidos California, Nueva Esperanza, Tres Picos, Josefa Ortiz de Dominguez, Sombra de la Selva, Francisco I. Madero, which are examples for farms and ejidos in the region and in the state of Chiapas. The objective is to document the method of transfer of a mathematical model, in its simplest expression towards the holders of the resource, to predict the production of resin by Pinus oocarpa tree in the Jorge de la Vega Domínguez ejido, Cintalapa, Chiapas.

\section{MATERIALS AND METHODS}

The ejido Jorge de la Vega Dominguez, municipality of Cintalapa, Chiapas, is located in the socioeconomic region II Valleys Zoque, where most of the forested areas are in an acceptable degree of conservation; perhaps because the predominant activity in the last ten years has been the exploitation of timber resources. However, there is astrong pressure towards these areas due to the need for spaces for agricultural activities (agricultural-livestock-coffee); the ejido has an area of 143 hectares dedicated for that purpose.

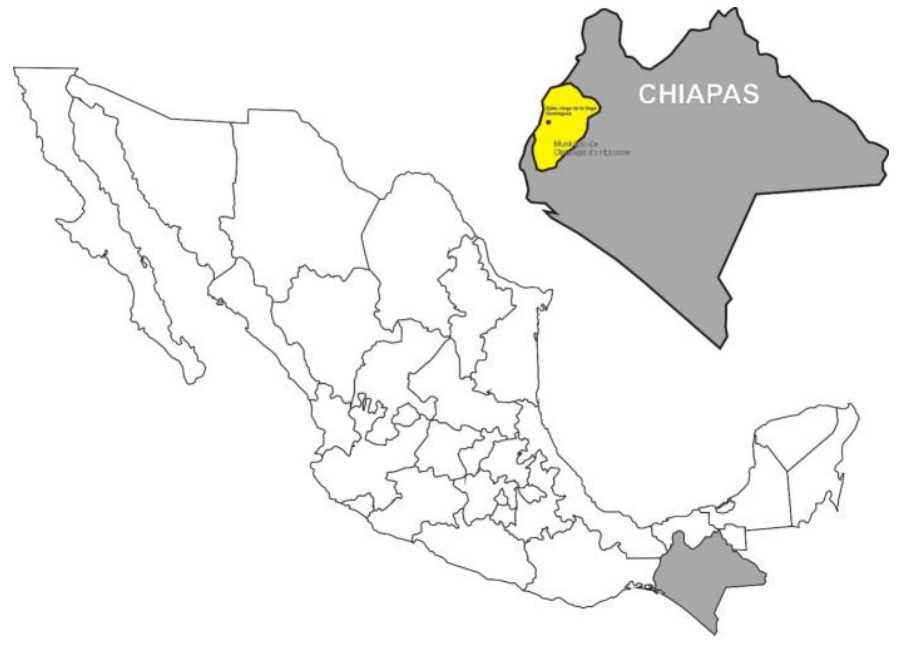


Figure 1. Geographical location of the Ejido Jorge de la Vega Dominguez, Municipality of Cintalapa de Figueroa, Chiapas, Mexico. INIFAP 2019.

However, the ejidatarios (small farmers) wish to continue with forest management in order to take advantage of Quercus Shumardii pine and oak trees, thus promoting the entry of economic resources for the basic needs of the family nucleus and the conservation of the forest areas of the ejido. The forest area is: 2,448 hectares, where different activities are carried out, which allow for the integral use of land, with activities such as: timber harvesting, non-timber forest harvesting, use of forest ecosystem services, etc. through mechanisms such as; timber management and non-timber forest management, protection and promotion of forest and wildlife resources, etc. The economy of the inhabitants of the Ejido Jorge de la Vega Dominguez, is based mainly on timber production, followed by the production of coffee Coffea arabiga, production of corn Zea mays L. and livestock production, these last three activities on a small scale. The production and commercialization of coffee, was drastically reduced by the lack of production per unit area due to the presence of orange rust Hemileia vastatrix, the lack of economic support and technical assistance by the government agencies responsible for this productive sector. What caused the abandonment of this crop by the producers; to achieve the maintenance of their families, the producers focused their efforts on other crops and livestock activities that generate economic resources, which can have an impact on the loss of forest cover in these areas and others that have been dedicated to conservation and production forest. The charcoal, although it is not transformed by the ejidatarios directly, is a source of income, taking into account that until now it is marketed from the standing oak tree, however, they have gradually entered into the production of charcoal. And if this activity is not regulated in a short time your resources will be greatly aggravated. Although the extraction of resin at the moment, has not been a constant source of income, in the same way as coal, this ejido had authorization for the timber harvesting of the first cutting cycle, issued by the Ministry of Environment and Natural Resources (SEMARNAT) since 2006, for a production area of 1,808 hectares. (Rosales, 2015; Management, Studies and Consulting for Conservation and Development S.C. 2015).

\section{CONSTRUCTION OF THE PREDICTIVE MODEL}

Definition of the study area. The geographical area where the data was taken determines the application area of the generated model, since its use outside this area can have as a consequence the underestimation or overestimation of tree resin. Due to this, a base map of the area was elaborated to have defined the land and vegetation uses present in the ejido, the generation of said map was through aerial photographs and satellite images. In any of the options, the field trips in coordination with the forestry technicians and with the owners or holders of the resource guaranteed a precise definition of the study area according to the following:

1. Location The geographical area where the field data was taken was a priority for the application of the generated model.

2. Accessibility. In order to facilitate the establishment work, a stand with the best road infrastructure was chosen.

3. Species The species of interest Pinus oocarpa was considered

4. Pure mass. A stand with a pure mass of Pinus oocarpa was preferred and this low use of resin. 
Sampling design and sample size. To estimate the production of pine resin per unit area, a fixed area plot of Pinus oocarpa was installed as a sampling unit. Subsequently, we proceeded to the installation of a number of sites in the previously selected stand, which were placed under a pattern of this type, at equidistance between sites of $100 \mathrm{~m}$, for this with the use of a GPS, and in coordinates geographic, they were located and installed. The type of sampling to be used was systematic, with quadrants of central point, which consists of measuring the tree in resin utilization closest to the center of the site. The quadrants were drawn according to the free directions $\mathrm{N}, \mathrm{S}, \mathrm{E}$ and $\mathrm{W}$, and were marked with the numbers from one to four, clockwise each of the trees was numbered progressively, based on the quadrant of belonging (Figure 2).

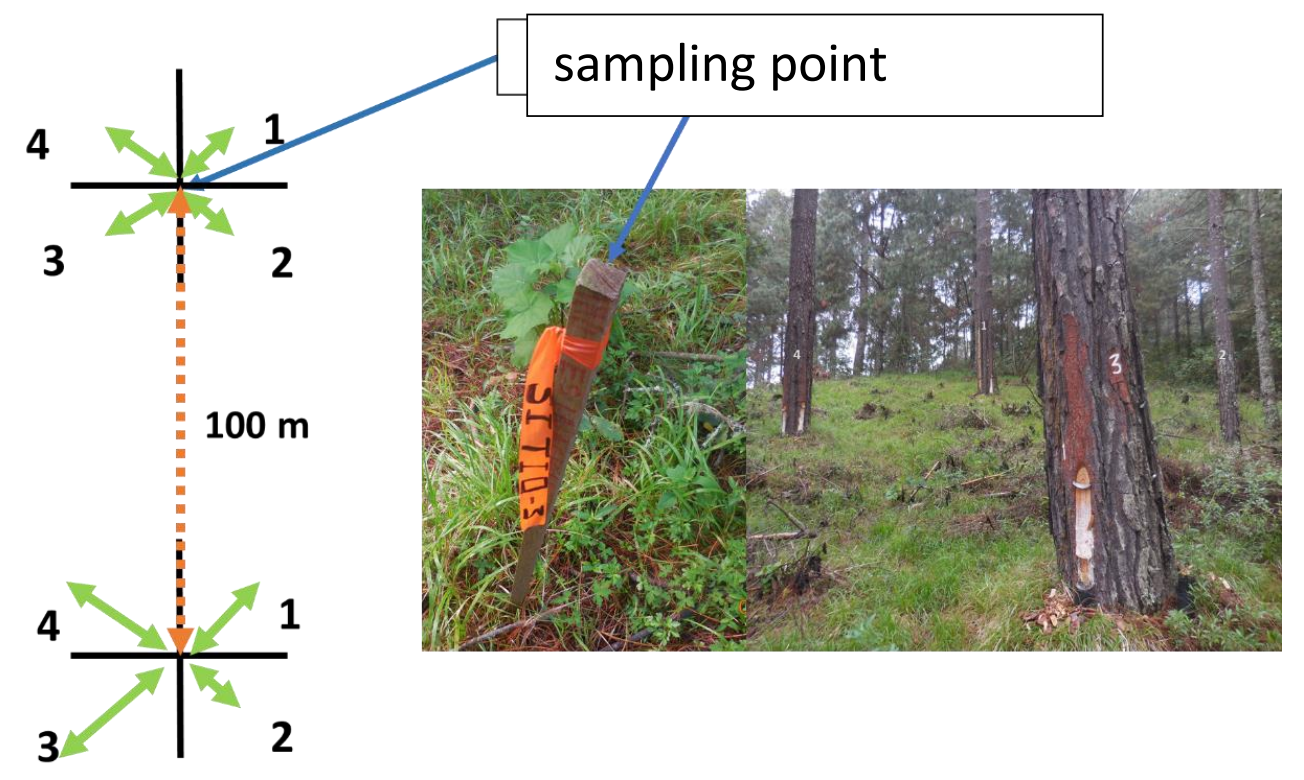

Figure 2. Example of systematic sampling using central point quadrants for the evaluation of Pinus oocarpa resin production in the Jorge de la Vega ejido. INIFAP, 2019.

Later with a longimeter the distance of the location of the tree under resination was measured, at the center of the site and marked with acrylic paint to identify them. In addition, the number of resin faces installed in each tree were also identified and recorded in an expressly designed format (Figure 3).

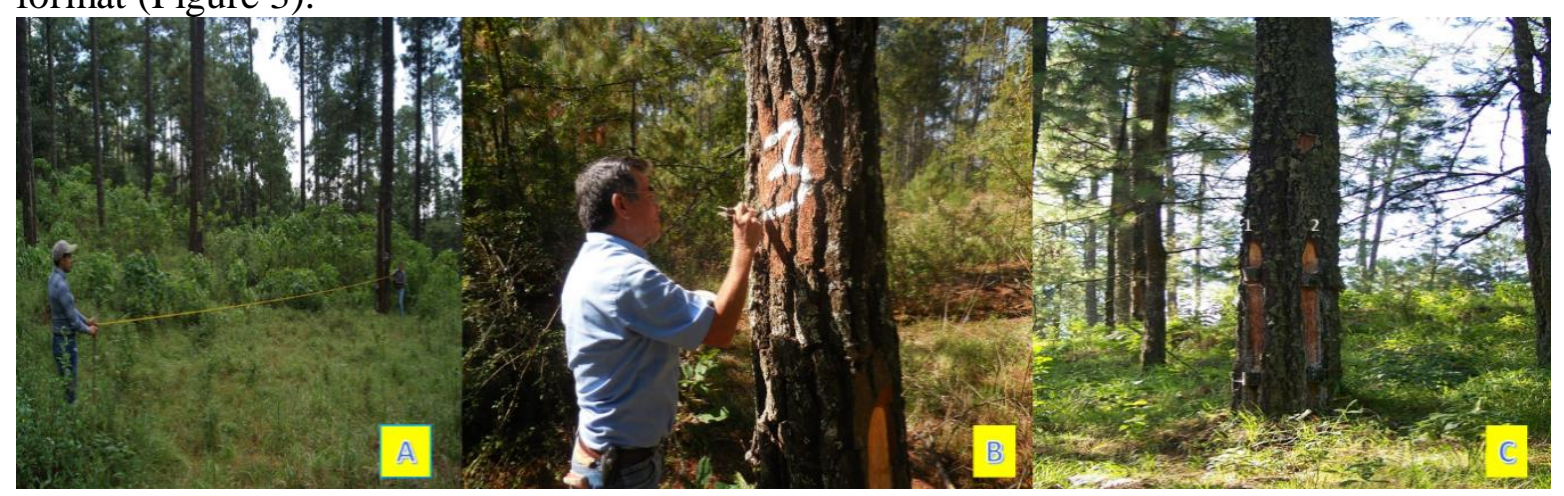


Figure 3. A) Measurement of the distance from the center point to the tree under resination B). Marking of trees C). Identification of number of installed faces. INIFAP, 2019.

Taking of the dasometric data. For the taking of field data, information was collected from the general data of the site of resination, as well as the evaluated dasometric variables, to each of the trees selected in the sampling sites were taken the following data: normal diameter, height of clean stem, total height, crown diameter, and age (Figure 4).

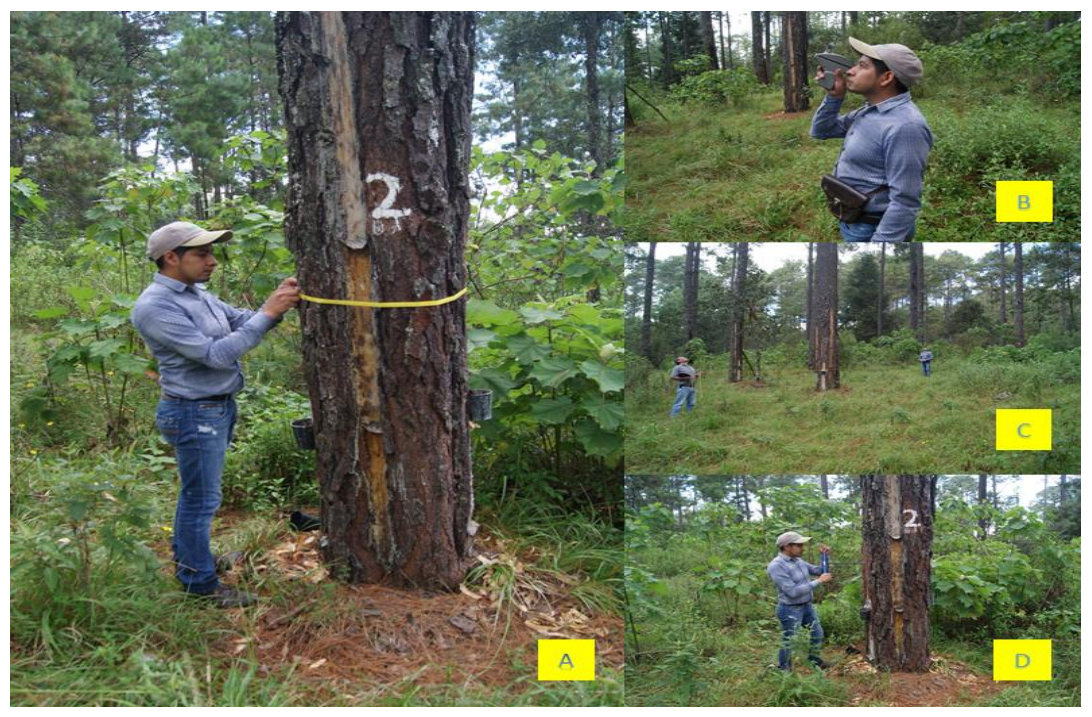

Figure 4. Example of taking dasometric data at the resination sites. TO). Normal diameter, B). Total height and height of clean shaft C). Cup diameter D). Age.

Normal diameter $(\mathbf{c m})$ : The measurement was made at $1.30 \mathrm{~m}$ above ground level, with a diametric tape graduated to tenth of a centimeter, taking the data from the top of the slope.

Height of the clean stem $(\mathbf{m})$ : The length of the stem comprised from the base of the tree to the first living branch of the crown was measured. A Haga pistol was used.

Total height (m): The vertical measurement of the tree from the base to the tip of the crown was recorded.

Cup diameter (m): The projection of the cup was measured in a north-south and east-west direction, with a tape measure.

Age (years): To estimate the age, the trees subject to resination were drilled, at the height of 1.30 $\mathrm{m}$, using Pressler's drill and counting the growth rings.

Process of the trees under resination, with the pica method of bark. The main tasks that will be carried out in the resination process for the preparation or assembly of the pine tree are the following:

"Desroñe": This activity consists of detaching the bark in the area of the trunk that is going to chop with a surface of $(20 \times 80 \mathrm{~cm})$. The main objective is to facilitate the subsequent work of making the incisions (pikes) (Figure 5). 
Placement of staple and pileup: In the lower part of the area called desroñe, the staple was placed making an incision in the trunk using a tool called half moon rounded profile, this was subject to the wood closed on it. The staple has the function of driving the resin towards the plastic container (Cacharro), which will fit between the staple and a tip nailed in the troco at the height of the base of the container (Figure 5).

Spades: the trees under resination were prepared for this process, with the "uela" tool. The depth of the pike was approximately $5 \mathrm{~mm}$, towards the interior of the wood, the third "pellet" was made horizontally, and from this height was executed with an inclination of $25^{\circ}$ to $30^{\circ}$, this action was made to facilitate the collection of the resin. Each new pike was made with a separation of 10 to $20 \mathrm{~cm}$ from the preliminary one in order to avoid the formation of stairs in the area of resination. The period between the pikes was about 10 days due to contact with air, the resin channels are clogged and no longer produces resin, so you should proceed to refresh this pike and climb a little upwards (Figure 5).

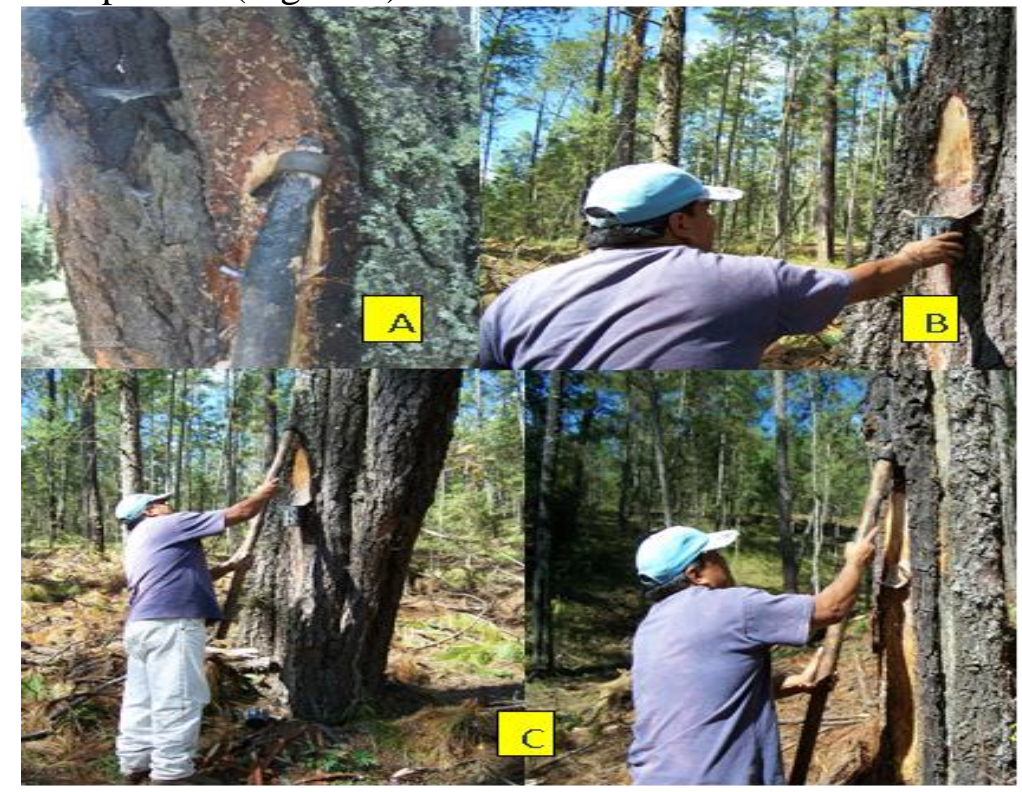

Figure 5. A) Desroñe. B) Placement of the staple and the pileup. C) Realization of the pikes with the pica method of bark in trees resinated in the sampling sites. INIFAP 2019.

Resin weight:This process of weighting the resin is done when the "Cacharros" were full of resin, which happened monthly and was evaluated over a period of four months. We used a portable scale graduated in grams and the recorded weight was highlighted the weight of the pileup. The determination of the weight was verified in all the faces of resination and it was registered in a format designed to exprofeso.

\section{RESULTS AND DISCUSSION}

Generation of the pine resin predictive model:Once the information has been collected per study unit (pine tree under the use of resin) it is possible to generate an equation to predict the amount of resin per year, based on dasometric variables. The method used for this process is a 
multiple regression, in which the dependent variable corresponds to the amount of resin $(\mathrm{kg})$ per tree and the independent ones are the dasometric variables, or a combination of them.In general, the multiple regression model is expressed as follows:

$\mathrm{y}=\beta 0+\beta 1 \mathrm{x} 1+\beta 2 \times 2+\beta 2 \times 3+\ldots+\beta \mathrm{k} \times \beta \mathrm{k}+\varepsilon(1)$

Where:

$y=$ Amount of resin produced by pine tree during a period of time, for example: a year

$\mathrm{x}^{\prime} \mathrm{s}=$ Independent variables indicated.

$\varepsilon=$ Normal and independent random variables with mean and unknown variance, but constant.

These were the assumptions of the model, whose compliance was verified.

For the creation of the predictive model the following steps were considered and consequently also the sessions of the field schools dealt with the following topics: 1. Definition of the study area, 2. Sampling design and sample size, 3. Taking of dasometric data, 4. Process of the trees under resination, with the pica method of cortex, 5. Weight of the resin, 6. Database, 7. Generation of the predictive model of pine resin, and 8. Production tables pine resin.

Pine resin production tables: As a result of this process, a pine resin production table was obtained, which was generated from the model built for said area. In the tables, the intersection of a row and a column will determine the estimated weight of pine resin per tree $(\mathrm{g})$. The production tables are easy to use by producers and technicians, who will be trained in their use. From the diameter and height of any tree, they can easily consult the estimated resin weight per tree.

\begin{tabular}{|c|c|c|c|c|c|c|c|c|c|c|c|c|c|}
\hline & & \multicolumn{12}{|c|}{$\mathbf{H}(\mathrm{m})$} \\
\hline No. FACES & $\mathrm{DN}(\mathrm{cm})$ & 10 & 12 & 14 & 16 & 18 & 20 & 22 & 24 & 26 & 28 & 30 & 32 \\
\hline 1 & 25 & 278.1 & 277.5 & 276.9 & 276.3 & 275.7 & 275.1 & 274.5 & 273.9 & 273.3 & 272.7 & 272.1 & 271.5 \\
\hline 1 & 26 & 278.4 & 277.8 & 277.2 & 276.7 & 276.1 & 275.5 & 275.0 & 274.4 & 273.9 & 273.3 & 272.7 & 272.2 \\
\hline 1 & 27 & 278.6 & 278.0 & 277.5 & 277.0 & 276.5 & 275.9 & 275.4 & 274.9 & 274.4 & 273.9 & 273.3 & 272.8 \\
\hline 1 & 28 & 278.8 & 278.3 & 277.8 & 277.3 & 276.8 & 276.3 & 275.8 & 275.3 & 274.9 & 274.4 & 273.9 & 273.4 \\
\hline 1 & 29 & 278.9 & 278.5 & 278.0 & 277.6 & 277.1 & 276.6 & 276.2 & 275.7 & 275.3 & 274.8 & 274.4 & 273.9 \\
\hline 1 & 30 & 279.1 & 278.6 & 278.2 & 277.8 & 277.4 & 276.9 & 276.5 & 276.1 & 275.7 & 275.2 & 274.8 & 274.4 \\
\hline 1 & 31 & 279.2 & 278.8 & 278.4 & 278.0 & 277.6 & 277.2 & 276.8 & 276.4 & 276.0 & 275.6 & 275.2 & 274.8 \\
\hline 1 & 32 & 279.3 & 279.0 & 278.6 & 278.2 & 277.8 & 277.5 & 277.1 & 276.7 & 276.3 & 276.0 & 275.6 & 275.2 \\
\hline 2 & 33 & 558.9 & 558.2 & 557.5 & 556.8 & 556.1 & 555.4 & 554.7 & 554.0 & 553.3 & 552.6 & 551.9 & 551.2 \\
\hline
\end{tabular}




\section{International Journal of Agriculture, Environment and Bioresearch}

Vol. 4, No. 04; 2019

ISSN: $2456-8643$

\begin{tabular}{|c|c|c|c|c|c|c|c|c|c|c|c|c|c|}
\hline 2 & 34 & 559.1 & 558.4 & 557.8 & 557.1 & 556.4 & 555.8 & 555.1 & 554.4 & 553.8 & 553.1 & 552.5 & 551.8 \\
\hline 2 & 35 & 559.3 & 558.7 & 558.0 & 557.4 & 556.8 & 556.1 & 555.5 & 554.9 & 554.3 & 553.6 & 553.0 & 552.4 \\
\hline 2 & 36 & 559.5 & 558.9 & 558.3 & 557.7 & 557.1 & 556.5 & 555.9 & 555.3 & 554.7 & 554.1 & 553.5 & 552.9 \\
\hline 2 & 37 & 559.6 & 559.1 & 558.5 & 557.9 & 557.4 & 556.8 & 556.2 & 555.7 & 555.1 & 554.6 & 554.0 & 553.4 \\
\hline 2 & 38 & 559.8 & 559.2 & 558.7 & 558.2 & 557.6 & 557.1 & 556.6 & 556.0 & 555.5 & 555.0 & 554.4 & 553.9 \\
\hline 2 & 39 & 559.9 & 559.4 & 558.9 & 558.4 & 557.9 & 557.4 & 556.9 & 556.4 & 555.9 & 555.3 & 554.8 & 554.3 \\
\hline 2 & 40 & 560.0 & 559.6 & 559.1 & 558.6 & 558.1 & 557.6 & 557.1 & 556.7 & 556.2 & 555.7 & 555.2 & 554.7 \\
\hline 2 & 41 & 560.2 & 559.7 & 559.2 & 558.8 & 558.3 & 557.9 & 557.4 & 556.9 & 556.5 & 556.0 & 555.6 & 555.1 \\
\hline 2 & 42 & 560.3 & 559.8 & 559.4 & 558.9 & 558.5 & 558.1 & 557.6 & 557.2 & 556.8 & 556.3 & 555.9 & 555.5 \\
\hline 3 & 43 & 840.5 & 839.9 & 839.3 & 838.7 & 838.0 & 837.4 & 836.8 & 836.2 & 835.5 & 834.9 & 834.3 & 833.7 \\
\hline 3 & 44 & 840.7 & 840.1 & 839.5 & 838.9 & 838.3 & 837.7 & 837.1 & 836.5 & 835.9 & 835.3 & 834.7 & 834.1 \\
\hline 3 & 45 & 840.8 & 840.2 & 839.7 & 839.1 & 838.5 & 837.9 & 837.4 & 836.8 & 836.2 & 835.7 & 835.1 & 834.5 \\
\hline 3 & 46 & 840.9 & 840.4 & 839.8 & 839.3 & 838.7 & 838.2 & 837.6 & 837.1 & 836.6 & 836.0 & 835.5 & 834.9 \\
\hline 3 & 47 & 841.1 & 840.5 & 840.0 & 839.5 & 839.0 & 838.4 & 837.9 & 837.4 & 836.9 & 836.3 & 835.8 & 835.3 \\
\hline 3 & 48 & 841.2 & 840.7 & 840.2 & 839.6 & 839.1 & 838.6 & 838.1 & 837.6 & 837.1 & 836.6 & 836.1 & 835.6 \\
\hline 3 & 49 & 841.3 & 840.8 & 840.3 & 839.8 & 839.3 & 838.8 & 838.4 & 837.9 & 837.4 & 836.9 & 836.4 & 836.0 \\
\hline 3 & 50 & 841.4 & 840.9 & 840.4 & 840.0 & 839.5 & 839.0 & 838.6 & 838.1 & 837.6 & 837.2 & 836.7 & 836.3 \\
\hline 3 & 51 & 841.4 & 841.0 & 840.6 & 840.1 & 839.7 & 839.2 & 838.8 & 838.3 & 837.9 & 837.4 & 837.0 & 836.5 \\
\hline
\end{tabular}

Pérezand Ortuño, $(\mathrm{SF})$ foundin Spain four aspects for a resins viability; the first of an economic type in which they point out that improving the exploitation techniques is very viable the activity of resination, another aspect is of a business type: ensuring the production of resin of better quality that implies that jobs must be maintained in the resin sector and this leads to the third aspect of social type, where the areas of use resinero are usually located on land that does not allow any other agricultural activity, so the disappearance of the resin sector would lead to a loss of jobs that is difficult can find accommodation in another economic activity, accentuating the problem of desertification or rural migration, the last aspect that these authors found was environmental, since the maintenance of forest areas for resination in those soils that do not 
represent other production expectations, it prevents erosion and deforestation. Something similar happens in the region of study in Jorge de la Vega, where if the extraction of resin in pinus Sppforests is not attended, the holders of the resource could expand the agricultural frontier in detriment of the forested surface.

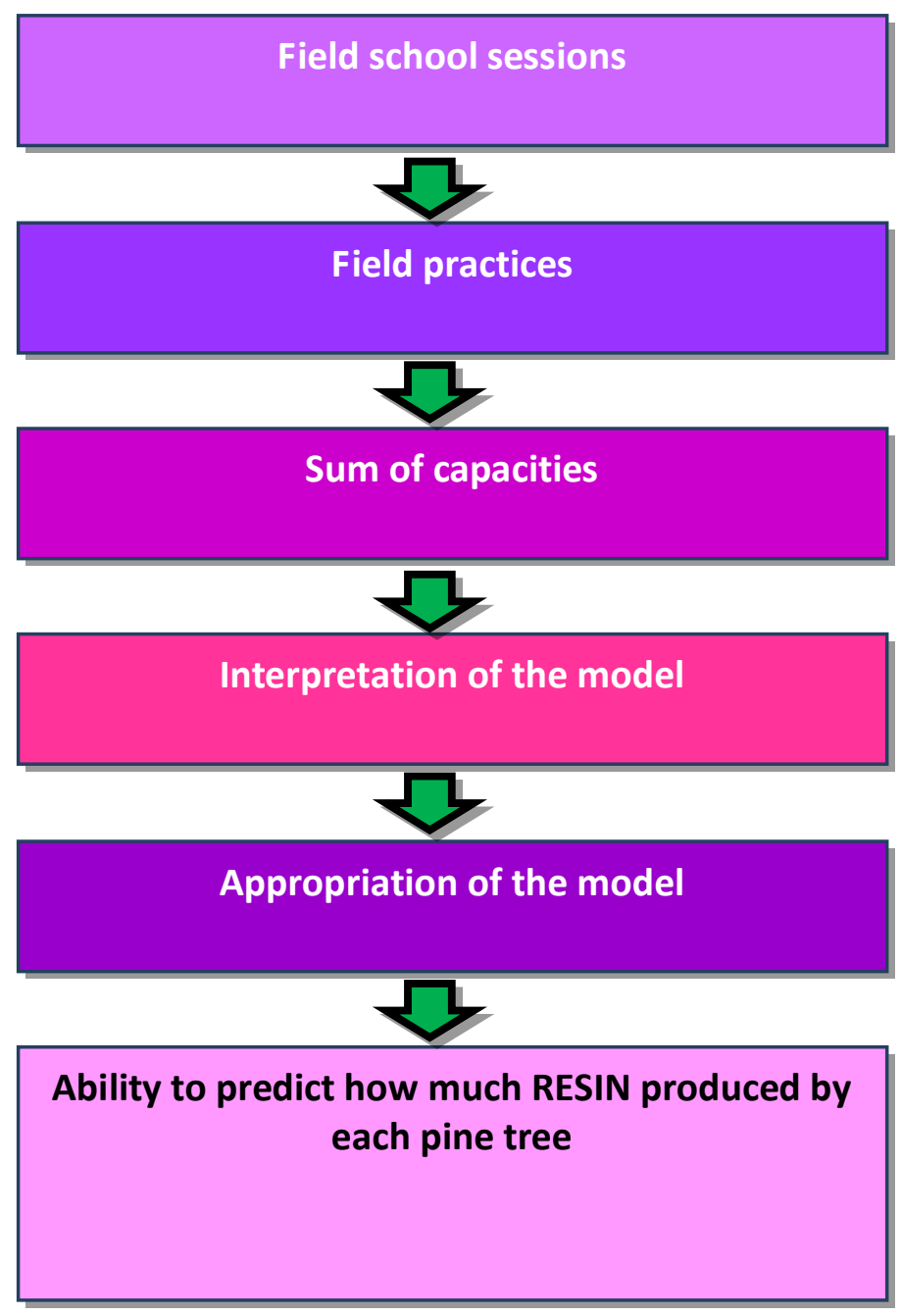

Figure 6. Transfer strategy through field schools to transfer the predictive model. INIFAP 2019.

Transfer strategy of the mathematical model for resin production: The strategy for transferring the technology and the predictive model was carried out in the following way, as shown in figure 6. Theoretical-practical sessions were carried out through the field schools, a methodology tool widely developed and operationalized by Gallagher (2003), Morales and Galomo (2006), Morales (2007), Morales (2008), Cadena et al., (2015), Cadena (2016) and 
Morales et al., (2016). Through dissemination and training events, given to forestry and technical producers, priority was given to the participation of young people, adults and women.

Demonstration plots (resination sites) were established, which were used to estimate the resin produced by face and tree, and at the same time as a place to train the aforementioned people. The plots of variable dimensions for obtaining dasometric data and resin production.

Although the Field Schools do not represent the only relevant activity in the transfer of knowledge, we must emphasize that this would have been possible without taking into account the activities to take into account the dasometric variables that allowed the development of the predictive model, with the combination of Both parties, field school sessions and training activities in the management of the dasometric variables, reached the following:

1. The Jorge de la Vega Domínguez ejido has a mathematical model that allows it to predict the production of resin by tree, surface and stand.

2. The ejidatarios who received the transfer of the technology, as well as the forestry technical service provider (PSTF) and the forestry promoter are trained in the process to estimate the production of resin produced by individual and by unit of area.

3. The ejido has the ability to apply the model in its mathematical form and through resin production tables.

4. There are 11 producers trained in different aspects of the methodology, which include the establishment of measurement sites, measurement of dasometric variables, quantification of resin and application of the predictive model.

5. Two demonstration plots were established where various training courses were developed.

6. A meeting was held between producers of the ejidos bordering Jorge de la Vega.

7. There are three agents of change or trained extensionists who can serve as trainers for other people in the methodology for the interpretation of the model.

There is a table for estimating resin production per tree depending on the trees' dasometric conditions, so that the owners of the resource can easily interpret and calculate the amount of resin that the tree can produce.

\section{CONCLUSIONS}

1. The proposed objectives were reached given that the predictive model was put in place to estimate resin production from Pinus oocarpa.

2. The producers have appropriated the methodology for the exploitation of the resin extractors in each producer tree

3. With the exchange of experiences between producers and with the training of local change agents, continuity is possible once the intervention team withdraws.

4. The existing potential for the extraction of non-timber products allows to approach better living conditions in an activity that was not previously carried out in the locality.

\section{REFERENCE}


1. Cadena, I. P. 2016. Las Escuelas de Campo (ECA): una estrategia de trabajo para zonas de alta marginación en México. En: Modelos alternativos de capacitación y Extensión Comunitaria. Edits. Jorge Aguilar Ávila y Vinicio Horacio Santoyo Cortés. Clave Editorial, Universidad Autónoma Chapingo. ISBN: 978-607-437-351-6. México D.F. pp: 141-160

2. Cunningham, A. 2009a. Estudio de mercado de los productos resinosos: Colofonia y aguarrás; y el potencial de la miera Ibérica de la Comarca del Izana para diferentes usos industriales. Mancomunidad de Bienes y Servicios del Rio Izana. 66 P.

3. Cunningham, A. 2009b. Estado actual de la resinación. Trabajo presentado en el XIII Congreso Forestal Mundial. Buenos Aires, Argentina. 7 p.

4. Gallagher, K. 2003. Elementos fundamentales de una Escuela de Campo. LEISA. Aprendiendo con las ECAS 19 (1): 4-7

5. Gestión, Estudios y Asesoría para la Conservación y el Desarrollo S.C. 2015. Programa predial de desarrollo integral de mediano plazo (PPREDIAL) del Ejido Jorge de la Vega Domínguez. Cintalapa, Chiapas. 43 p.

6. Hernández, J. 2011. Aprovechamiento sustentable y comercialización de resina de pino. Ponencia. Morelia, Michoacán. 164 p.

7. Mas P., J. y A. Prado. 1981. Comparación del método de resinación de pica de corteza con estimulantes contra el método francés. INIF. Edición: 2. Boletín Técnico. No. 35. 20 p.

8. Morales-Guerra, M. y Galomo-Rangel, T. 2006. Escuelas de campo; experiencia de desarrollo de capacidades para la transferencia de tecnología en comunidades indígenas. Instituto Nacional de Investigaciones Forestales, Agrícolas y Pecuarias. Centro de Investigación Regional Pacífico Sur. Campo Experimental Valles Centrales de Oaxaca. Santo Domingo Barrio Bajo, Etla, Oaxaca. ISBN: 970-43-0043-3, 172 p.

9. Morales-Guerra, M. 2007. Manual de Escuelas de Campo para la capacitación y transferencia de tecnología. Centro de Investigación Regional Pacífico Sur. Campo Experimental Valles Centrales de Oaxaca. Santo Domingo Barrio Bajo, Etla, Oaxaca. Libro técnico Núm. 10. 48 p.

10. Morales-Guerra, M. 2008. Manual de Escuelas de Campo; guía metodológica. Centro de Investigación Regional Pacífico Sur. Campo Experimental Valles Centrales de Oaxaca. Santo Domingo Barrio Bajo, Etla, Oaxaca. Libro Técnico Núm. 8. 48 p.

11. Morales, G. M; Hernández Galeno, C.A. y Vásquez, O.J.A. 2016. Escuelas de Campo. Un modelo de capacitación y acompañamiento técnico para productores agropecuarios. Centro de Investigación Regional Pacífico Sur. Campo Experimental Valles Centrales de Oaxaca. Santo Domingo Barrio Bajo, Etla, Oaxaca. Folleto técnico Núm. 48. ISBN: 978607-37-0492-2. $37 \mathrm{p}$.

12. Pérez-Rebollo, J.L. and Ortuño-Pérez, S.F. (SF). Estudio de viabilidad de nuevas técnicas para España La resinación. Forestal. Dpto. Economía y Gestión de las Explotaciones e Industrias Forestales E.T.S.I. Montes. Madrid. Visitado el 08 de julio de 2019https://infomadera.net/uploads/articulos/archivo_2529_10069.pdf

13. Romahn-de la Vega., C.1992. Principales productos forestales no maderables de México. Universidad Autónoma Chapingo. Texcoco, México. 376 p. 
14. Rosales Arroyo, Florentino. 2015. Estudio técnico justificativo para el aprovechamiento de recursos forestales no maderables: Resina de pino del Ejido Jorge de la Vega Domínguez Municipio de Cintalapa, Chiapas. 34 p.

15. Secretaría de Medio Ambiente, Recursos Naturales y Pesca. 2006. Especies con usos no maderables en bosques de encino, pino y pino-encino en los estados de Chihuahua, Durango, Jalisco, Michoacán, Guerrero y Oaxaca. Pinus pseudostrobus Lindl. Procymaf. In: http://www. semarnat.gob.mx/pfnm/Pinus pseudostrobus.html (Disponible 09 de agosto del 2016).

16. Secretaría de Medio Ambiente y Recursos Naturales. 2014. Anuario Estadístico de la Producción Forestal. SEMARNAT. México. 236 p.

17. Zamora-Martínez, M.C., E. Velasco B., A. González H., C. Nieto de Pascual P., F. Moreno S., M.E. Romero S. y A. Flores G. 2009. Modelos Predictivos para la Producción de Productos Forestales No Maderables: Hongos. Manual Técnico Núm. 1. CENIDCOMEF. INIFAP, México, D.F. México. 58 p. 